\title{
A travel journal of pastoral involvement in a South African multi-faith community
}

\author{
Jan-Albert van den Berg \& Arnold Smit ${ }^{1}$ \\ Department of Practical Theology \\ University of the Free State
}

\begin{abstract}
In the article the process of navigating through multi-faith communities is described as often being complicated by well-travelled routes that offer no new prospects. Usually these routes merely lead to a further erosion of existing problem areas. The consequences of large transformations in South Africa have led to the discovery that those who were able to place themselves theologically with ease are now seekers with an unknown destination who experience their existence as pilgrimage. From a narrative hermeneutical practical stance the authors developed an experimental theology within which continuous dialogue between text and contexts is presupposed. Certain markers, amongst others "Listening to each other's stories"; "Confirming each other in the conversation(s"); "A new structure for conversation(s)"; and "Questioning the own position" are indicated for the journey through multi-faith communities, leading to the finding and creating of new horizons of understanding.
\end{abstract}

\begin{abstract}
Sharmaine is an Indian woman orientated towards the Hindu faith. One day, her husband, who was still young, died unexpectedly while she was at work. Except for the fact that she and her children were shocked, her colleagues too were distressed by the events. From the reports I received, it was clear that she was totally overwhelmed by the events and that a visit to her house was the appropriate way of supporting her to come to terms with her husband's death. During the visit, the religious background of the family became apparent, amongst others, in the religious Hindu symbols that were visible. During the conversation, she talks about her loss and the fact that she is incapable of supporting the children in coping with their bereavement. She also talks about her struggle with God. With her permission, I pray for her and her children.
\end{abstract}

\footnotetext{
${ }^{1}$ This article was originally presented as part of an Intercultural Forum at the $18^{\text {th }}$ International Seminar on Intercultural Pastoral Care and Counselling, 1-7 October 2005, Düsseldorf, Germany. Dr Jan-Albert van den Berg is a senior lecturer in the Department of Practical Theology, Faculty of Theology, University of the Free State, and Dr Arnold Smit is a H R Executive at Channel Life, Johannesburg.
} 


\section{MAPPING THE JOURNEY}

The title of this contribution, as well as the narrative case study above, articulates a journey. The metaphor of a travel journal presupposes that we shall record, amongst others, aspects of the journey through a particular landscape. By using the medium of a narrative description we seek to describe the portrayed reality in full colour. While we are aware of the reality of various maps and routes for this landscape, we shall take a bearing of religion and spirituality, as overlapping degrees of longitude and latitude, for an own mapping. The domain of religion presupposes "... a cultural codification of important spiritual metaphors, narratives, beliefs, rituals, social practices, and forms of community among a particular people ... " (Griffith and Griffith 2002:17). Spirituality, however, is mapped as " ... the search for purpose and meaning in one's life" (Damianakis 2001:23). The journey through this landscape is being articulated in the fluidity of step between narrative case studies (practice) of pseudonymous travellers, elucidated by perspectives from theoretical travel diaries (theory) with new accents on further determining the route (practice) (Browning 1991:84).

\section{THE LANDSCAPE OF THE JOURNEY}

On journey through a teenager South African democratic disposition, the landscape is marked by a constitution, which leaves ample room for the optimal protection of religious rights (Du Plessis 2002:228). In contrast with the landscape that was left behind in 1994, "The country and its government ... [is] not 'Christian' any more ... The public broadcaster is expected to reflect the religious plurality of the population ... Even the educational system moved away from the vestiges of the 'Christian National' ideology" (Kritzinger 2000:99). This new map of South Africa, with the emphasis on a multireligious understanding of the landscape, was born in this classroom. Western Christians formerly imposed their idea of a Christianised civilisation on the communities in the country, and education became the vehicle by which it was institutionalised (Van Niekerk 1982:104-109). In our opinion, this was one of the reasons why the debate on religious education in schools raged fiercely in the new South Africa for quite a while. It seemed as though education first had to be "freed" from being dominated by Christianity.

While we are aware of the fact that religious plurality presupposes different institutes and organisations (Vos 2000:180), it remains given that the people of Africa is highly religious and that religion influences every sphere of African society. Moyo (2001:299) is correct in writing: "It is a way of life in which the whole community is involved, and as such it is identical with life itself." 
The consequences of this larger transformation have led to the discovery that those who, snugly, were able to place themselves theologically with ease previously, now, were seekers with unknown destination who experience their existence as pilgrimage (Van der Meulen 2004:62). The significance of this for people orientated on the Christian faith was already articulated earlier from the American context by Gerkin (1986:16): "This means that Christian language for interpreting the meaning of things, evaluating human actions and attitudes, and formulating human purposes is now only one language among many and no longer can claim consensual legitimation." As Christians, were are now starting to become aware of the fact that our own theological movement is in jeopardy if we do not reposition ourselves or, in terms of the metaphor, deliberately meet the other (religious) travellers along the route to our future.

Except for the new South African religious landscape, the authors' personal travel diaries are also being articulated differently. Both of them were fulltime ministers of the Dutch Reformed Church for a number of years, after which Jan-Albert became a lecturer at a Theological Faculty with a reformed ecumenical character. Arnold first worked as an ecumenical consultant for congregations, but, for the recent past, he has been working in the private sector as a human resource manager in a company with a very diverse composition of staff, representing all creeds and cultures of the South African community.

\section{TRAVELLING}

As we are aware of the fragmentation of the old maps of a separate and marginalised world, we share the opinion of Browning (2000:91) that theology "... in the future increasingly must express itself within a pluralistic society of diverse religio-cultural assumptions, differing cultural disciplines, and conflicting ethical patterns of life". In our opinion, one of the best possible routes to take in order to meet these requirements is to choose to describe practical theology as a narrative hermeneutical practical theology (Gerkin 1986:20; Gerkin 1997:111-113; Müller 2000:17).

Among others, the journey is navigated by important paradigmatic shifts within the landscape of pastoral theorising. Louw (1999:21-27) points to the movement from an individual approach to taking account of contexts; from explaining problems in a one-sided fashion to a hermeneutical understanding; from kerugma to construing and storytelling, and from one-sided professional emphasis to collectively caring for each other. 
When choosing the narrative hermeneutical practical theology, the landscape is couched in a post-modern tint within which there is room for variety and for the diversity of culture (Singh \& Kotzé 2002:183). Early in the journey through South Africa's new landscape, already, the "turn to relationships" (Grenz 2003:252) becomes an accent with particular significance. With the emphasis on relationships, the needle of the compass is on more than a mere meeting, but indeed on profound involvement with each other (Müller 1996:15).

This theological itinerary acquires a further African nuance if the metaphorical nature of faith is strongly emphasised. "In Africa metaphors are deeply embedded in a culture determined by a spiritual world and a communal awareness of co-humanity (ubuntu)" (Louw 2004:32). We realise the journey in a post modern landscape by using social constructivism as a vehicle (Müller 2000:56-59). By this, we do not pretend that this is the only vehicle through this landscape, but that it is tailor made for our particular journey. It is our presupposition that this vehicle is exactly suitable for the terrain of hermeneutics and for understanding the human map-making as systemic in nature. Social constructivism is suitable for the journey because it promotes dialogue (Gergen 2002:283) in the way in which it provides space for the "... challenge of communicating across the boundaries between different denominations and different religious communities" (Schweitzer 2002:176). With this in mind, we set off on the journey on a double-track road through South Africa on which one of the tracks allows us to taste the dust of contextuality and the other leads us to the highway of a network(s) of relationships.

\section{ON THE JOURNEY OF ENCOUNTERS THROUGH DIALOGUE - A POSSIBLE WAY OF TRAVELLING ...?}

In a first conversation with Donovan, an Indian man orientated on the Hindu faith, he told me the story of his marriage. He did not know why he was telling this to me, because he had never before discussed it with anybody else. This morning, we had had a second conversation. This time, it was about his daughter who is ill. A week ago, she upset them with sudden tantrums. He and his wife suspected that an evil spirit has taken possession of her, and had asked Hindu religious leaders to come and pray for her. Donovan also obtained a medical diagnosis, which indicated that the girl suffers from temporal epilepsy. It is clear that Donovan's bondage to culture and religion places him on two tracks: on the one hand, the child needs to take the medicine regularly and, on the other hand, the evil spirit needs to be kept in check by prayers. 
In my discussion with Donovan concerning the role of spirituality, I tried to explain that, in fact, it means that one has to be sensitive for the circumstances in which the illness and the concomitant behaviour can be managed optimally. I told him about our son's leukaemia and the treatment thereof over a period of three years. I explained that we did not move the responsibility to believe to him, but that we took it upon ourselves to be stewards of his potential to regain his health. The conversation took place while I was aware of Donovan's orientation on the Hindu faith and while he was aware of my Christian orientation.

In a possible description of how, as a Christian, to start out on a journey with others in the multi-faith community in South Africa, as expressed by Donovan's story above, we develop an experimental theology within which continuous dialogue between text and context are presupposed (Bosch 1991:427). In order to enter the space of intercultural and inter-religious communication, it is necessary that "... tolerance, mutual respect, and even appreciation of the other" (Schweitzer 2002:176) be present. The co-ordinates of these concepts are being indicated for us in the Christian conceptualisation of hospitality:

\begin{abstract}
Hospitality means inviting the stranger into our private space, whether that be the space of our own home or the space of our personal awareness and concern. And when we do so, some important transformations occur ... Hospitality to the stranger gives us a chance to see our own lives afresh, through different eyes.
\end{abstract}

(Palmer 1992:69)

In setting foot on this new terrain together with other conversation partners, we readily take our lead from Schweitzer (2002:177-178) and Griffith \& Griffith (2002:30-46) who indicated certain markers on the route to conversation:

\title{
4.1 Listening to each other's story(s)
}

Central to the first beacon of a possible route to conversation is the significance of the narrative metaphor, which, amongst others, presupposes that our stories: are determining our lives, are determined by the context, are multi-levelled in nature with dominant and alternative descriptions, and that the narrator is the best guide of an own story (Griffith \& Griffith 2002:83-84).

In listening to others' stories, the real content thereof can only be heard if the conversation partners depart together in a communitas-commitmment on a pilgrimage for new meaning (Griffith \& Griffith 2002:23). 


\section{A travel journal of pastoral involvement in a South African multi-faith community}

By using biographical and autobiographical material, the discourses of person and culture are being brought under discussion on a non-threatening manner. In retelling and listening to each other's stories, different discourses and the role thereof are identified jointly between conversation partners (Freedman \& Combs 1996:42-43; Burman \& Kottler; Levette \& Parker 1997:2). It is especially the restrictive nature of culturally determined discourses (Lester 1995:137; De Lange 2004:38) that are being exposed in order to create space to develop a new understanding (Freedman \& Combs 1996:xiv-xv; Griffith \& Griffith 2002:75).

Discovering a new understanding becomes clear in the conversation below in which a woman comments from particular presuppositions on the recent explosions in London. The pastoral therapist tries to enlarge her singularly dominant description of the Islam faith with alternative possibilities:

On July, 13, 2005, Susan walked into my office with a newspaper in her hand. Apparently, fundamentalist Muslims are responsible for the four explosions in London in which more than 50 people died. As a Christian, she is upset and wonders what type of religion it is that mobilises people to be suicide bombers? In a discussion in which, amongst others, the concept of stereotyping is explored, I discovered with her that other descriptions of people who adhere to the faith of Islam also exist. The conversation also helped Susan to reconstruct alternative descriptions for the word Christian.

\subsection{Confirming each other in the conversation(s)}

On the road of possible encounters, involvement with each other is important (Müller 1996:16). Involvement with each other is found in the relieves and contours of participation where "... we see that 'all otherness' becomes 'one' in relational process" (Gergen 2002:288). The character of this involvement is filled by the following:

What one brings to a genuine encounter is not first and foremost an ensemble of communication techniques but one's self and, to be more precise, the depth one has to share. The dept in one-self develops through a whole-hearted engagement with others, with life, with God.

(Pembroke 2002:13)

It is in being involved with others that we come to discover that there is a difference between, on the one hand, being merely a spectator and, on the other hand, actively being part of the process of involvement and participation. 
Then we take seriously in our lives the potential of the stranger to be a teacher.

God uses the stranger to shake us from our conventional points of view, to remove the scales of worldly assumptions from our eyes. God is a stranger to us, and it is at the risk of missing God's truth that we domesticate God, reduce God to the role of familiar friend.

(Palmer 1992:59)

In this way, the character of our involvement with the other is formed not from a position of power or from an attitude of "knowing" but from being receptively, open-minded and teachable. Obviously, this does not mean that the pastoral therapist does not know anything (Freedman \& Combs 1996:44) or does not have an own orientation of faith, which, for instance, from a commitment to the Christian faith, offers a perspective on the world (Bosch 1991:9). What it does mean, however, is that we choose for a particular mode of working in our involvement with others that afford the space for enhancing inquisitiveness, openness and amazement as our dominant emotions (Griffith \& Griffith 2002:48). Amongst others, this leads to our trusting less in putting questions while trusting more in meticulously listening to others (Freedman \& Combs 1996:44-45).

\subsection{Discovering a possible structure in conversation(s)}

Francois enters my office. He received a message that the father of Miriam Letswayo, one of his team members, has died. She has not yet been informed about it and it is his task to break the news to her. He has never before handled something like this and is uncertain about what to do. I ask him to call one of her best friends immediately to help us. She will best know how to support Miriam. From previous experience, I have learned that black people handle a death message differently from white people. They cry differently from us as westerners and they differ in helping one another. Francois and I witness a process whereby black friends and colleagues participate in Miriam's grief. By bodily contact and encouraging words, Miriam is calmed until she is able to talk about what has happened. Some white members of the staff also try to comfort Miriam, but in a more formal and more distanced way. I feel that we are treading on the holy ground of another culture. We have a great deal to learn.

We find the background to discovering a possible structure for conversation(s) in Palmer's (1992:46) distinction between, amongst others, "public space" and 
"public myth". "Public space" refers to spaces where people can become aware of the presence of strangers and can facilitate mutual involvement. "Public myth" refers to the worldview within which people find the opportunity to define their own situatedness. The metaphor of a "rainbow nation" endowed South Africa with such a myth. The challenge remains for the Christian churches and other religious groups to offer such situatedness to the inhabitants of South Africa in terms of which they will be able to understand their own context.

Within a Christian context, we think that merely acknowledging that we need to discover, through our involvement with each other, that "reality is a stranger and even more multi-layered than we could have imagined ..." (Veldsman 2000:159) is already helping the process a great deal. In a multicultural South Africa, which also has the accent of a multi-faith orientation, we as pastoral therapists are focussing on democratising the structure of pastoral therapy in order to facilitate openness and respect (Griffith \& Griffith 2002:36). The democratisation of the pastoral conversation is asking for a sensitivity regarding the balances of power in the conversation(s) in which it is not about changing the conversation partner, but rather about understanding the stories of others. This new space is entered, as was shown in the previous narrative case study when we continuously and conjointly look for the significance of, amongst others, metaphors and rituals in order to understand important life issues (Louw 2004:38). This means that one conversation only can never be enough, but that the first, second, and tenth conversation always leads to the next discovery that asks to be explored and articulated.

\subsection{Questioning the own position}

It is only the conversational partner who dares to question own presuppositions when determining an own position that can dare to enter into conversation with the other. Questioning the own position creates the possibility to hear and understand the other from a position of "not-knowing" (Freedman \& Combs 1996:44; Morgan 2000:2). In enquiring about taking an own position, we enquire about the influence of cultural values and norms, which again determine personal identity and self-image (Müller 2000:17-18). In determining an own philosophical position in life, insight into a pre-modern, modern, and postmodern disposition can be crucial for the conversation (Hendriks 2004:56).

Given our history, it is precisely our greatest risk, that is that we do not want to abdicate power, but are merely trying to shift the terrain in which we are trying to exercise power. The Christian ethos does not allow this. 
Regarding the significance of this for the work of the pastoral therapist, it is proper to let Arnold articulate an own position:

As I am currently working, as a theologian, in the private sector, surrounded by the cultural and religious diversity of the South African society, I am often forced to reflect on my theological roots. I was taught to articulate and defend the Christian faith, to witness of that in which I believe. Also, I taught others this way while I was still a minister and was preaching. Now I am in that context about which I had so much advice for others (read Christians) and I realise that it deals with something totally different, namely, to minister mercy to others. This is the test for the question whether others will invite me to listen to their travelling journals. I suspect that I am not being consulted by 'others' because I know "the Way", but because I try to be a merciful travelling partner.

In reflecting about what it means to be such a merciful travelling partner for others, we wonder about Christ's message for multi-cultural and multireligious environments. What can we deduce from the story of Christ regarding crossing borders, conduct towards strangers, providing hospitality and ministering mercy to others? Perhaps, metaphorically spoken and deriving from the image of the vine in John 15, it is the pain of intercultural and inter-religious pruning processes, that is that we are trying to bear fruit on the wrong rootstock if dogmatic orientation is determining our dealings with other cultures and religions. The rootstock we need is precisely to be able to live amongst others and to be able to create a living space in the style of Christ. For that, we have to be grafted into another rootstock, namely Christ. Perhaps the Christian life style is, in its best presuppositions and amidst other religions, an unexpectedly fit orientation with which to live within and to the advantage of diversity. That is why Forward (2000:252) can say:

I gained the belief that: pastoral theology is about God's providential care of all his creation, including me; that life is open to the impress of God's guidance of others and me; that religious faith and obedience are open-ended; that pluralism is dealing with the bewildering diversity of means and goals.

In this approach, we confirm that faith in God is precisely about overcoming brokenness and fragmentation by, amongst others, reconciliation with so called strangers (Palmer 1992:26). This is exactly what Paul tells of through his ancient carrying out of faith under the central theme of God's mercy (Ac 17:26) and where the Gospel becomes the space where people, with their plural experiences, are accepted by God (Vos 2000:181). For us, as 
Christians, this space is defined by "... a community of compassion" (Palmer 1992:87) with the knowledge that "... we find our deep unity with others not by seeking to embrace them, but by letting God embrace us (Palmer 1992:109).

\subsection{Together finding and creating a new horizon(s)}

Indira, an Indian woman and a follower of the Dalai Lama, came to see me about being reprimanded at work for using the phone excessively. She experienced it as questioning her integrity. She talked freely about her religious devotion. She told me, amongst other things, about the spirituality centre that she visits over weekends, about the work they do in communities, and about her passion for people who suffer. Together, we considered strategies that can clear her motives by responsibly using the telephone at work. We thought about things that can enable her to convince others that she is a woman of integrity and that she is deserving of their trust. The conversation also led me to believe that she wants to become a contributor to the company's corporate social investment projects as well.

In the conversation, it is clear that both conversation partners can come to understand each other's distinctive worlds, presuppositions, and motives. However, this does not only lead to understanding one another better, but also opens new perspectives to a greater understanding of life.

In discovering newly fused horizons of understanding (Gerkin 1986:101), an experience of liminality is created, which leads to a "... 'transitional space', as a domain of experience that bridges the internal, subjective world of an individual with reality as it is experienced by the external, objective community" (Griffith \& Griffith 2002:25).

\section{ONCE AGAIN, CONTINUING THE JOURNEY}

Navigating through multi-faith communities is often complicated by welltravelled routes that offer no new prospects and just lead to the further erosion of existing problem areas. The metaphors people can choose from to describe this journey is often becoming narrowing. Such a metaphor is the image of the mountain, which sees different religions merely as different roads leading to the top of the mountain. Perhaps, the possibility of new roots asks for the map to be turned in another direction in order to show that no map is showing only one mountain, but that "They may, in fact, be ascending quite different mountains ..." (Forward 2000:252).

In the journey through the mountainous landscape of the new situation in South Africa, the stranger(s) is challenging our established points of view (Palmer 1992:59) and leading us to the point where we as Christians do not 
have to focus only on the identity of others, but also on understanding ourselves. It is in reflecting on identity that Christians discover that " $A$ demarcation line exists, but the focus is not on 'maintaining the boundary' but 'on reaffirming the center'. The center of a person who is a new creation in Christ is constituted by separation, but around the center there is space for otherness" (Volf 1997:66).

Continuing the journey on the road of encounters through dialogue, we wonder whether this is not exactly the effect that Africa has on us? Not entering into a discourse with each other that is informed by only a western moulded discourse in which we struggle for the neat formulation of the truth, but an "ubuntu" related discourse in which time and space exist for mutual influence. In this discourse there is space for stories, within which the wisdom is fed by what we perceive in others and around us (Moyo 2001:299).

For us, the abovementioned travel journal is an invitation, time and again, to go on a journey through the multi-faith landscape of South Africa to possibly discover "... unique answers to contextual issues..." (Smit 2001:10). Travelling, we are trying to make sense from the differing narratives fusing on a new horizon of understanding. In this fusion, we also find the significance of pastoral care with Gerkin (1986:64) when he writes: "The purpose of practical theological thinking is always the facilitation of the transformation of life."

\section{Works consulted}

Bosch, D J 1991. Transforming mission: Paradigm shifts in theology of mission. New York: Orbis Books.

Browning, D S 1991. A fundamental practical theology. Minneapolis, MN: Fortress.

Browning, D 2000. Pastoral theology in a pluralistic age, in Woodward, J and Pattison, A (eds), The Blackwell Reader in Pastoral and Practical Theology, 89-103. Oxford: Blackwell.

Burman, E, Kottler, A, Levett, A \& Parker, I 1997. Power and discourse: Culture and change in South Africa, in Levett, A, Kottler, A, Burman, E \& Parker, I (eds), Culture, power and difference, 1-14. Cape Town: University of Cape Town Press.

Damianakis, T 2001. Postmodernism, spirituality, and the creative writing process: Implications for social work practice: Families in society. The Journal of Contemporary Human Services, 23-34.

De Lange, F 2004. Modern life course as "Choice biography", in Ganzevoort, R R \& Heyen, $\mathrm{H} \mathrm{K}$ (eds), Weal and woe: Practical-theological explorations of salvation and evil in biography, 34-49. Münster: LIT Verlag.

Du Plessis, L M 2002. Grondwetlike beskerming vir godsdiensregte as groepregte in Suid-Afrika. NGTT 43(1\&2), 214-229.

Forward, M 2000. Culture, religious faiths, and race, in Woodward, J and Pattison, S (eds), in The Blackwell Reader in Pastoral and Practical Theology, 248-256. Oxford: Blackwell Publishing.

Freedman, J \& Combs, G 1996. Narrative therapy: The social construction of preferred realities. New York: W W Norton. 
Gergen, K J 2002. Reflecting on/with my companions, in Hermans, C A M Immink, G, de Jong, A \& van der Lans, J (eds), Social constructionism and theology, 273289. Leiden: Brill.

Gerkin, C V 1986. Widening the horizons: Pastoral responses to a fragmented society. Philadelphia, PA: Westminster.

Gerkin, C V 1997. An introduction to pastoral care. Nashville, TN: Abingdon.

Grenz, S J 2003. Ecclesiology, in Vanhoozer, K J (ed), Postmodern theology: The Cambridge companion to postmodern theology, 252-268. Cambridge: Cambridge University Press.

Griffith, J L \& Griffith, M L 2002. Encountering the sacred in psychotherapy: How to talk with people about their spiritual lives. New York: Guilford.

Hendriks, H J 2004. Studying congregations in Africa. Wellington: Lux Verbi.

Kritzinger, J J 2000. Mission in the new South Africa: Need for a renewed enquiry. Skrif en Kerk 21(1), 93-114.

Lester, A D 1995. Hope in pastoral care and counselling. Louisville, KY: Westeminister John Knox.

Louw, D J 1999. Pastoraat as vertolking en ontmoeting. Wellington: Lux Verbi.

Louw, D J 2004. A pastoral paradigm for God-Images in an African context, in Foskett, J and Larty, E (eds), Spirituality and culture in pastoral care and counselling: Voices from different contexts, 31-42. Cardiff: Cardiff Academic Press.

Morgan, A 2000. What is narrative therapy?: An easy-to-read introduction. Adelaide: Dulwich Centre.

Moyo, A 2001. Religion in Africa, in Gordon, A A \& Gordon, D K (eds), Understanding contemporary Africa, 299-329. London: Lynne Riener.

Müller, J C 1996. Om tot verhaal te kom: Pastorale gesinsterapie. Pretoria: Raad vir Geesteswetenskaplike Navorsing.

Müller, J C 2000. Reis-geselskap: Die kuns van verhalende pastorale gesprekvoering. Wellington: Lux Verbi.

Palmer, P J 1992. The company of strangers: Christians and the renewal of America's public life. New York: Crossroad.

Pembroke, N 2002. The art of listening: Dialogue, shame, and pastoral care. Grand Rapids, MI: Eerdmans.

Schweitzer, F 2002. Social constructionism and religious education: Towards a new dialogue, in Hermans, C A M, Immink, G, De Jong, A \& Van der Lans, J (eds), Social constructionism and theology, 171-185. Leiden: Brill.

Singh, L \& Kotzé, D 2002. Ethical and cultural dilemmas of an Indian pastoral therapist, in Kotzé, D, Myburg, J, Roux, J \& Ass (eds), Ethical ways of being, 183-201. Pretoria: Ethics Alive.

Smit, A 2001. Meetings that matter: Leadership, spirituality and discernment in congregations. Wellington: Lux Verbi.

Van der Meulen, H C 2004. De Pastor als reisgenoot: Pastoraal-theologische gedachten over geestelijke begeleiding. Zoetermeer: Uitgeverij Boekencentrum.

Van Niekerk, A S 1982. Dominee, are you listening to the drums? Cape Town: Tafelberg.

Veldsman, D P 2000. Imagine substituting leptons and quarks for gods and spirits.

Skrif en Kerk 21(1), 156-171. 
Volf, M 1997. Exclusion and embrace: Theological reflections in the wake of "ethnic cleansing" in, Gundry-Volf, J M \& Volf, M (eds), A spacious heart: Essays on identity and belonging, 33-66. Pennsylvania, PA: Trinity.

Vos, C J A 2000. Kerk en teologie in die jaar nul. Skrif en Kerk 21(1), 172-193. 